\title{
Multiple Drug Resistance Patterns in Various Phylogenetic Groups of Hospital-Acquired Uropathogenic E. coli Isolated from Cancer Patients
}

\author{
Ahmed Talaat Mahmoud ${ }^{1}$, Mohamed Taha Salim ${ }^{1}$, Reham Ali Ibrahem ${ }^{2}$, Adel Gabr ${ }^{3}$ and \\ Hamada Mohamed Halby 1 ,* \\ 1 Department of Microbiology and Immunology Faculty of Pharmacy Al-Azhar University, Assuit 71524, \\ Egypt; ahmedabdel-al@azhar.edu.eg (A.T.M.); mohamedsalem@azhar.edu.eg (M.T.S.) \\ 2 Department of Microbiology and Immunology Faculty of Pharmacy El-Minia University, Minia 61111, Egypt; \\ Reham.ali@mu.edu.eg \\ 3 Department of Medical Oncology and Malignant Hematology, South Egypt Cancer Institute, Assuit \\ University, Assuit 71515, Egypt; Adelgabre@yahoo.com \\ * Correspondence: hamadahalby@azhar.edu.eg
}

Received: 26 December 2019; Accepted: 20 February 2020; Published: 2 March 2020

\begin{abstract}
Cancer patients are more susceptible to several bacterial infections, particularly urinary tract infections caused by uropathogenic E. coli (UPEC). The objective of this work was detection and the phylogenetic characterization of hospital-acquired isolates of uropathogenic E. coli in cancer patients and the determination of its relation with antibiotic resistance. A total of 110 uropathogenic E. coli responsible for hospital-acquired urinary tract infections in cancer patients were included in this study. A triplex PCR was employed to segregate different isolates into four different phylogenetic groups (A, B1, B2 and D). Drug resistance was evaluated by the disc diffusion method. All of the isolates were multiple drug-resistant (MDR) and 38.18\% of all UPEC isolates were extended-spectrum beta-lactamase (ESBL) producers from which 52\% were positive for the blaCTX-M gene, $40 \%$ for the blaTEM gene, and 17\% for the blaSHVgene. Among 42 ESBL-producing uropathogenic E. coli isolates, the majority belonged to phylogenetic group B2 (43\%), followed by group D (36\%), group A (19\%) and group B1 (2\%). Our results have shown the emergence of MDR isolates among uropathogenic E. coli with the dominance of phylogenetic group B2. Groups A and B1 were relatively less common. The most effective drug in all phylogenetic groups was imipenem.
\end{abstract}

Keywords: uropathogenic E. coli; phylogenetic analysis; drug resistance

\section{Introduction}

Escherichia coli (E. coli) is the most prevalent commensal inhabitant of the gastrointestinal tract (GIT) of humans and animals. It is a common pathogen linked with community-associated as well as hospital-acquired infections [1]. Hospital acquired infections (HAIs) are the major cause of life-threatening complications in hospitalized patients, especially immunocompromised patients, such as cancer patients [2]. Urinary tract infections (UTI) caused by E. coli strains are the most common cause of morbidity in hospitalized cancer patients due to their several impairments of host defense [3].

Cancer is the leading cause of death worldwide. The most important risk factors for HAIs in cancer patients are surgical operations, extensive use of medical devices and immunosuppression [4].

The cancer patient is immunocompromised due to the underlying malignancy, such as leukemia, and also due to the destructive complications of cancer treatment, such as chemotherapy, radiation, and bone marrow transplantation. This could lead to prolonged immunosuppression, increasing the risk of infection and possibly worsening the prognosis [5]. 
The increased resistance of $E$. coli to antibiotics has been frequently reported from different regions of the world as a complication of treatment. Antibiotics given empirically without suitable antibiotic sensitivity testing are considered as the major causes for the emergence of multidrug resistance. The current awareness of the organism that causes UTI and their antibiotic susceptibility is obligatory to ensure appropriate therapy. The dissemination of ESBL-producing E. coli in the hospital setting is a problem with major therapeutic and epidemiologic consequences [6].

E. coli was classified into four major phylogenetic groups: A, B1, B2 and D. The phylogenetic analysis was done by a simpler method targeting three genetic markers: chuA (required for heme transport), yjaA (unknown function) genes and a DNA fragment, TSPE4.C2. The virulent strains, including UPEC, belong to phylogenetic groups B2 and D and the less virulent and commensal isolates belong to $\mathrm{B} 1$ and $\mathrm{A}$ [7].

The evolution and spread of various phylogenetic groups of antibiotic-resistant $E$. coli became a worldwide health concern in human medication, so the assessment of the phylogenetic distribution of antimicrobial-resistant E. coli is vital for therapeutic and economic functions [8]. Thus, according to the importance of different $E$. coli phylogenetic groups and the role of its antibiotic resistance pattern. The aim of this study is the detection of phylogenetic groups of uropathogenic E. coli, determination of the antibiotic resistance profile of uropathogenic E. coli, and assessment of the relation between phylogenetic groups and antibiotic resistance of uropathogenic E. coli.

\section{Results}

The total number of urine samples received during the study period (from March 2018 to March 2019) was 212, out of which significant bacterial growth was observed in 152 (71.7\%) samples. Out of 152 urine samples, E. coli was isolated from 110 (72.4\%) samples (Figure 1).

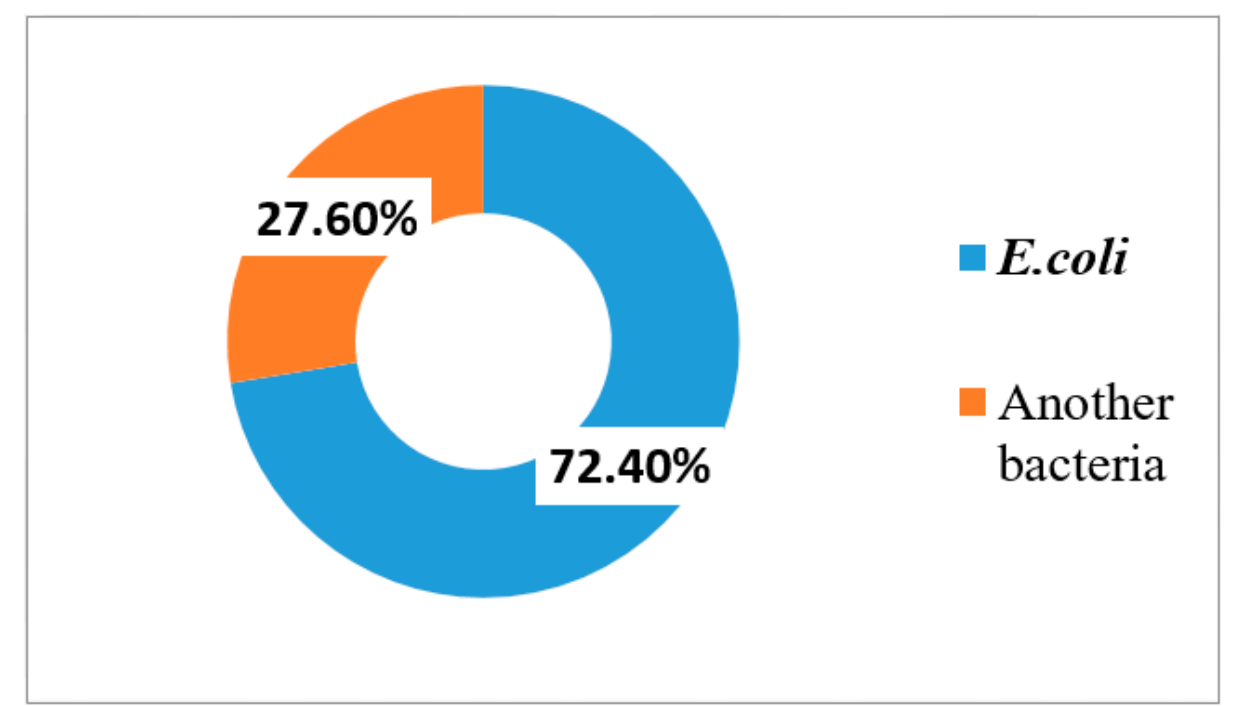

Figure 1. Percentage of patients with E. coli infection and non-E. coli infection among the isolates.

\subsection{Antimicrobial Sensitivity Pattern of Uropathogenic E. coli Isolates}

The antibacterial susceptibility profile was examined in all 110 uropathogenic E. coli isolates. The resistance rate to each antibiotic was calculated as the number of resistant isolates divided by the total number of isolates (Table 1). 
Table 1. Antimicrobial sensitivity pattern of uropathogenic E. coli isolates.

\begin{tabular}{cccc}
\hline \multirow{2}{*}{ Antimicrobial Agent } & Resistance Rate & \multirow{2}{*}{ Antimicrobial Agent } & Resistance Rate \\
\cline { 2 - 2 } & No (\%) & & No (\%) \\
\hline Ceftriaxone & $90(81.8 \%)$ & Amikacin & $32(29.09 \%)$ \\
Cefotaxime & $86(78.1 \%)$ & SXT & $88(80 \%)$ \\
Aztreonam & $78(70.9 \%)$ & Gentamycin & $47(42.73 \%)$ \\
Ceftazidime & $82(74.5 \%)$ & Ciprofloxacin & $66(60 \%)$ \\
Cefepime & $78(70.9 \%)$ & Levofloxacin & $50(45.45 \%)$ \\
Imipenem & $24(21.8 \%)$ & Colistin & $36(32.73 \%)$ \\
Nitrofurantoin & $28(25.4 \%)$ & - & - \\
\hline
\end{tabular}

\subsection{Phenotypic Detection of ESBL}

A total of 51 E. coli isolates (46.63\%) were found as potential ESBL producers, they showed reduced susceptibility to one or more of ceftazidime, aztreonam, cefotaxime or ceftriaxone. Out of 51 isolates that were considered as potential ESBL producers, 42 (38.18\%) were confirmed as ESBL producers.

\subsection{Genotypic Detection of ESBL Producers by Polymerase Chain Reaction}

All confirmatory screened uropathogenic E. coli isolates were analyzed by PCR for the detection of ESBL genes. It was found that CTX-M was the main type of ESBL, TEM was the second, and then SHV as shown in Table 2 and some strains had more than one genotype of ESBL genes. The detection of these genes by gel electrophoresis is shown in Figure 2.

Table 2. Distribution of ESBL genes in uropathogenic Escherichia coli isolates.

\begin{tabular}{ccc}
\hline \multirow{2}{*}{ ESBL Genes } & \multicolumn{2}{c}{ Positive } \\
\cline { 2 - 3 } & No. & $\%$ \\
\hline CTXM & $22 / 42$ & 52 \\
TEM & $17 / 42$ & 40 \\
SHV & $7 / 42$ & 17 \\
CTXM + TEM + SHV & $1 / 42$ & 2.38 \\
CTXM + TEM & $7 / 42$ & 16.67 \\
CTX-M + SHV & $5 / 42$ & 11.90 \\
TEM + SHV & $2 / 42$ & 4.76 \\
\hline
\end{tabular}

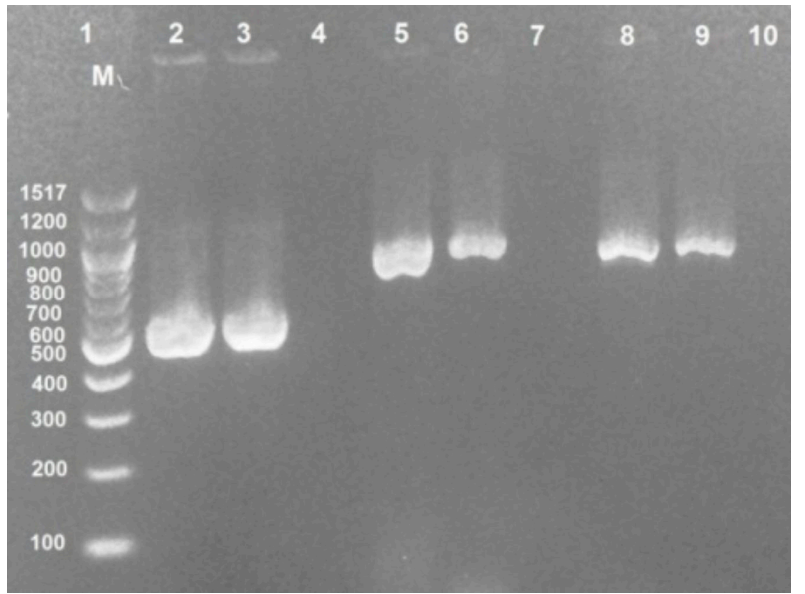

Figure 2. Distribution of ESBL genes in uropathogenic Escherichia coli isolates. Lane (1): DNA marker 100 bp. Lane (3): CTX-M gene (544 bp). Lane (6): TEM gene (867 bp). Lane (9): SHV gene (867 bp). Lane $(2,5,8)$ : Positive control (Escherichia coli ATCC25922). Lane $(4,7,10)$ : Negative control. 


\subsection{Distribution of Phylogenetic Groups in ESBL Producer-UPEC Isolates}

Strains were assigned to phylogenetic groups based on the presence or absence of the three genes: chuA, YjaA, and TspE4.C2. Phylogenetic analysis of isolates indicated that the majority of uropathogenic E. coli isolated from suspected cases of UTI of cancer patients belonged to group B2 and $\mathrm{D}$, as shown in Table 3. The detection of these genes by gel electrophoresis is shown in Figure 3.

Table 3. Distribution of Phylogenetic groups in EP-UPEC isolates.

\begin{tabular}{cccccc}
\hline $\begin{array}{c}\text { Phylogenetic } \\
\text { Group }\end{array}$ & $\begin{array}{c}\text { No. of } \\
\text { Isolates }\end{array}$ & $\begin{array}{c}\text { Distribution According } \\
\text { to Gene Grouping }(n)\end{array}$ & chuA & YjaA & TspE4.C2 \\
\hline B2 & $18(43 \%)$ & 14 & + & + & + \\
& & 4 & + & + & - \\
D & $15(36 \%)$ & 13 & + & - & - \\
B1 & $1(2 \%)$ & 1 & + & - & + \\
A & $8(19 \%)$ & 5 & - & - & + \\
& & 3 & - & - & - \\
\hline
\end{tabular}

$[+]=$ Positive, $[-]=$ Negative.

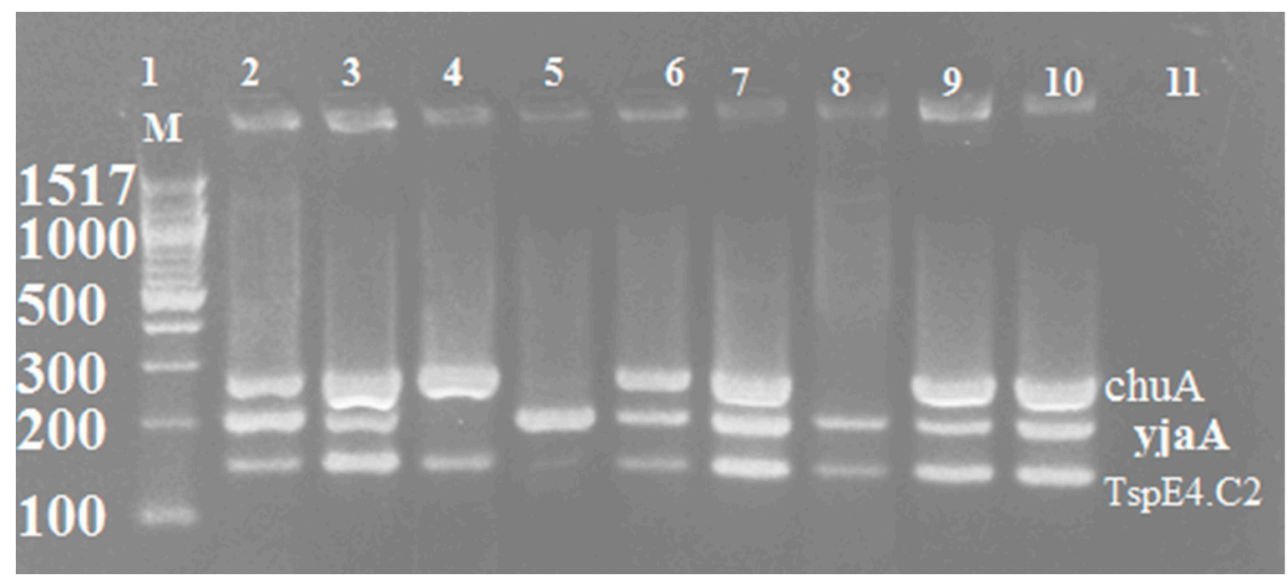

Figure 3. Multiplex PCR of amplified phylogenetic groups. Lane (1): DNA marker $100 \mathrm{bp}$. Lane (2, 3, 6, 7, and 9): chuA gene (279 bp) and yjaA gene (211 bp) and TspE4.C2 (152 bp). Lane (4): chuA gene (279 bp) and TspE4.C2 (152 bp). Lane (5): yjaA gene (211 bp. Lane (8): yjaA gene (211 bp) and TspE4.C2 (152 bp). Lane (10): Positive control (Escherichia coli ATCC25922). Lane (11): Negative control.

\section{Discussion}

Cancer patients are known to be susceptible to various nosocomial infections due to the destructive complications of cancer treatment on their immune system [4]. Urinary tract infection (UTI) is one of the major causes of morbidity in cancer patients. E. coli was the most common organism isolated in cancer patients with UTI [3].

In this study, the urine culture was taken from cancer patients, which showed that $71.7 \%$ were positive. This result is similar to that reported by Tancheva et al. [9] in Varna where the rate was $68 \%$. However, it is higher than that reported by Yakovlev et al. [10] in India, where the rate was $33.4 \%$ and Raad et al. [11] in Finland found that UTI was present in $12.5 \%$ of cancer patients.

This study revealed that the main isolated organisms from urine culture taken from cancer patients were Escherichia coli (72.4\%). This is comparable with previous studies reported by Bhusa et al. [12] in the USA, Tancheva et al. [9] in Varna, Mukta et al. [13] in India, and Chandra et al. [14] in India but with lower rates than our study, where the rates were $69.5 \%, 64.7 \%, 38.09 \%, 37.5 \%$, respectively.

Antibiotic resistance is a major clinical problem when treating UTI in cancer patients caused by UPEC. The resistance to imipenem seen in our study, which is more than any other previous study, 
perhaps finds a logical explanation due to the frequent use of imipenem as routine treatment for resistant strains. Other studies reported lower rates of resistance to imipenem, such as Sedighi et al. [15] in Iran, who reported it to be 3.3\% and Mukta et al. [13] in Bulgaria, who found the resistance to be 9\%. In addition, Elsayed et al. [16], in Egypt, reported that the resistance rate was 2\%. The lower resistant rates for imipenem are probablybecause it is a very powerful drug used only in hospital settings and not as first-line therapy in out-patients clinics [17].

In our study, E. coli isolates exhibited maximal resistance against ceftriaxone. This finding is quite challenging because ceftriaxone is a commonly-used empirical therapy in most hospitals. This result is similar to that reported by Mahgoub et al. [18] in Egypt, where the rate was 79.6\%. However, the result in this study is higher than that reported by Abdel-Moaty et al. [19] in Egypt and Khan et al. [20] in Bangladesh, where the rates were $61 \%$ and $41.9 \%$, respectively.

The regional variations of resistance to antibiotics may be explained by different local antibiotic practices. The influence of inappropriate antibiotic use on the event of antibiotic-resistant strains, especially broad-spectrum agents, has been proven through empirical observation [21].

Extended-spectrum $\beta$-lactamase (ESBL) production is an important resistance mechanism that inhibits the antimicrobial actions against infections caused by Enterobacteriaceae. ESBLs are considered a serious threat to the currently available antimicrobial agents [22]. The prevalence of bacteria producing ESBLs varies worldwide, with reports from North America, Europe, South America, Africa and Asia [23].

Preliminary detection of ESBL-producing E. coli isolates was done by screening tests according to CLSI (2016) that depend on reduced susceptibility to one or more of cefotaxime, ceftazidime, aztreonam, cefotaxime or ceftriaxone. Accordingly, 46.63\% (51/110) of UPEC isolates were considered as potential ESBL producers. This is comparable with Shakya et al. [24] in Nepal who reported that $43.8 \%$ of UPEC isolates were potential ESBL producers by screening tests.

In addition, a similar result was obtained by Alqasim et al. [25] in Saudi Arabia who reported that $41 \%$ of UPEC isolates were potential ESBL producers, but a higher rate of potential ESBL-producing UPEC was reported by Al-Mayahie et al. [26] in Iraq, Thabit et al. [27] in Egypt and Mukherjee et al. [28] in India, where the rates were $80.2 \%, 76.47,70 \%$, respectively. For the ESBL confirmatory double-disk synergy test, DDST detected ESBLs in $42 / 110$ (38.18\%). This percentage is similar to the result by Alqasim et al. [25] in Saudi Arabia who reported that 33.3\% of UPEC isolates were confirmed ESBL producers by DDST. Furthermore, Islam et al. [29] in Bangladesh reported a comparable result where $32 \%$ of UPEC isolates were confirmed ESBL producers by the same test.

Higher levels of ESBL production were reported by Al-Mayahie et al. [26] in Iraq, Chandra et al. [14] in India, Al-Agamy et al. [30] in Egypt, Mekki et al. [31] in Sudan, and Abayneh et al. [32] in Southwest Ethiopia. The rates reported for each study were $64.8 \%, 62.5 \%, 60.9 \%, 53 \%$ and $76.5 \%$, respectively. In contrast, lower results were mentioned by Sedighi et al. [15] in Iran (27.3\%) and Villanueva et al. [33] in the Philippines (12.4\%).

In our study, a higher degree of resistance was shown by ESBL producers than ESBL non-producers. The obtained results revealed that the resistance level to all cephalosporins (cefotaxime, ceftazidime, ceftriaxone, and cefepime) and aztreonam was significantly higher in ESBL-producing E. coli in comparison with non-ESBL-producing isolates $(p<0.001)$. This finding is in accordance with other reports, such as Islam et al. [29] in Bangladesh, and Abdel-Moaty et al. [19] in Egypt.

In the current study, ESBL-producing isolates exhibited significantly higher resistant rates to non- $\beta$-lactamase antimicrobials agents including fluoroquinolone, aminoglycosides, tetracycline and trimethoprim/sulfamethoxazole, compared to non-ESBL-producing isolates. The possible explanation for this observation may be that ESBLs are encoded on plasmids and can be mobile and therefore, easily transmissible as resistance gene elements for other antimicrobials from one organism to another.

In the present study, the genotyping of ESBL-producing UPEC isolates was done by PCR to determine the most common ESBL genes responsible for resistance. We reported that CTX-M was the main ESBL type (52\%), followed by TEM ( $40 \%)$, then SHV (17\%). Twelve isolates had more than one 
type of ESBL, where CTX-M + TEM were found in 7 (16.67\%) isolates, CTX-M + SHV were observed in $11.9 \%$ of isolates and $4.76 \%$ of isolates had TEM + SHV genes. The same order of gene type presence, but with different percentages, was reported by Chakraborty et al. [34] in India, where the CTX-M gene was detected in $88 \%$ of E. coli, followed by TEM (19\%) and SHV (2\%). In addition, the same pattern was mentioned by Zhao et al. [35] in China, who reported that the rate of CTX-M, TEM, and SHV among E. coli isolates was $42.5 \%, 4.2 \%$, and $0.8 \%$, respectively.

The increase of consumption of cefotaxime and ceftazidime could have contributed to the emergence of CTX-M enzymes encoding genes among E. coli strains in Egyptian hospitals [36].

CTX-M $\beta$-lactamases constitute a novel and rapidly growing family of plasmid-mediated ESBLs, which are currently replacing mutant TEM or SHV ESBL families [6].

In contrast, Azargun et al. [37] in Iran, reported that the TEM gene was the major ESBL gene in UPEC isolates, followed by the CTX-M gene and the SHV gene, where the rates for TEM, CTX-M, and $\mathrm{SHV}$ were $75.6 \%, 78.6 \%$ and $33.3 \%$, respectively.

In our study, Triplex PCR-based phylogenetic analysis was carried out for EP-UPEC isolates according to the method described by Clermont et al. [7]. Phylogenetic grouping revealed that most of the isolates belonged to the B2 group $(n=18,43 \%)$, followed by group $\mathrm{D}(n=15,36 \%)$, group A $(n=8,19 \%)$ and group B1 (2\%). The majority of studies concerning the phylogenetic grouping among UPEC have reported a similar distribution, such as Zhao et al. [35] in china, Abdi et al. [38] in Iran, Lee et al. [39] in Korea, Johnson, and Stell [40] in Minnesota, Picard et al. [41] in France, Ejrnæs et al. [42] in Denmark, Kanamaru et al. [43] in Japan, and Alghoribi et al. [44] in England.

However, a few studies have reported a different distribution of phylogenetic groupings for UPEC isolates, such as Marialouis et al. [45] in India who found that most of the isolates belonged to B2, followed by A, B1, and D, and phylogenetic group D isolates were the least frequent. In addition, Bashir et al. [46] in Pakistan observed the same finding with their phylogenetic analysis.

In contrast, some studies observed that most of the UPEC isolates belonged to phylogenetic group D, followed by A, B1, and B2, such as Adwan et al. [47] in Palestine and Abdallah et al. [48] in china, where phylogenetic group B2 isolates were the least frequent phylogenetic group.

The results of drug resistance according to phylogenetic groups are shown in Table 4. Our findings showed that group B2 was the most predominant phylogenetic group and most resistant strain to commonly used antibiotics among patients. This finding is in agreement with other studies such as Iranpour et al. [49] in Iran. However, Bashir et al. [46] in Pakistan reported that group B2 isolates exhibited lower levels of drug resistance than our study.

Table 4. Prevalence of antimicrobial resistance in phylogenetic groups of EP-UPEC isolates.

\begin{tabular}{|c|c|c|c|c|c|c|c|c|c|}
\hline Antimicrobial Agent & \multicolumn{2}{|c|}{ B2 } & \multicolumn{2}{|c|}{$\mathbf{D}$} & \multicolumn{2}{|c|}{ B1 } & \multicolumn{2}{|c|}{ A } & $\frac{p \text {-Value }}{\%}$ \\
\hline Ceftriaxone & 18 & 100 & 15 & 100 & 1 & 100 & 7 & 87.50 & 0.226 \\
\hline Aztreonam & 17 & 94.44 & 15 & 100 & 1 & 100 & 4 & 50.00 & 0.003 * \\
\hline Ceftazidime & 18 & 100 & 15 & 100 & 1 & 100 & 6 & 75.00 & 0.030 * \\
\hline Nitrofurantoin & 13 & 72.22 & 3 & 20.00 & 0 & 0 & 3 & 37.50 & 0.017 * \\
\hline Amikacin & 5 & 27.78 & 3 & 20.00 & 0 & 0 & 1 & 12.50 & 0.777 \\
\hline Gentamicin & 8 & 44.44 & 7 & 46.67 & 0 & 0 & 2 & 25.00 & 0.608 \\
\hline Levofloxacin & 9 & 50.00 & 6 & 40.00 & 1 & 100 & 3 & 37.50 & 0.629 \\
\hline Ciprofloxacin & 14 & 77.78 & 10 & 66.67 & 1 & 100 & 1 & 12.50 & 0.012 * \\
\hline
\end{tabular}


In our study, group D isolates were totally resistant to ceftriaxone, aztreonam, and ceftazidime, but highly resistant to cefotaxime (93.3\%), cefepime (86.8\%), sulfamethoxazole/trimethoprim $(73.33 \%)$ and ciprofloxacin (66.67\%), and less resistant to gentamicin (46.4\%), imipenem (33.3\%), amikacin (20\%), nitrofurantoin (20\%) and levofloxacin (40\%). This result is similar to Bashir et al. [46]. In contrast, Iranpour et al. [49] in Iran found that group D isolates exhibited a low level of drug resistance.

In this study, Group A isolates were totally sensitive to imipenem and sulfamethoxazole/trimethoprim, less resistant to gentamicin $(25.4 \%)$, amikacin $(12.5 \%)$, nitrofurantoin $(37.5 \%)$, levofloxacin $(37.5 \%)$, colistin $(12.5 \%)$ and ciprofloxacin $(12.5 \%)$, and highly resistant to ceftriaxone $(87.5 \%)$, ceftazidime $(75 \%)$, cefotaxime $(87.5 \%)$, cefepime $(62.5 \%)$ and aztreonam $(50 \%)$. In contrast, Bashir et al. [46] in Pakistan found that group A isolates showed a higher level of drug resistance than our study.

In our study, we observed a significant difference between phylogenetic groups and resistance to different groups of antibiotics. This finding is similar to the study reported in china by Wang et al. [50]. In contrast, Cristea et al. [51] in Romania found that their statistical analyses did not reveal any statistical significance of the correlation between antibiotic resistance and $E$. coli phylogenetic groups.

The frequency of blaCTX-M, blaTEM and bla SHV ESBL genes in phylogenetic groups is summarized in Table 5. Our phylogenetic analysis of the isolates revealed that strains harboring CTX-M gene were associated with the D phylogenetic group and there is a significant difference was observed in the frequency of CTX-M type between the phylogenetic groups.

Table 5. Prevalence of ESBL genes in phylogenetic groups of uropathogenic Escherichia coli isolates.

\begin{tabular}{|c|c|c|c|c|c|c|c|c|c|c|}
\hline \multirow{3}{*}{$\begin{array}{c}\text { ESBL } \\
\text { Genes }\end{array}$} & \multirow{3}{*}{ Total } & \multirow{2}{*}{\multicolumn{2}{|c|}{$\begin{array}{c}\text { B2 } \\
N=18\end{array}$}} & \multirow{2}{*}{\multicolumn{2}{|c|}{$\begin{array}{c}\text { D } \\
N=15\end{array}$}} & \multirow{2}{*}{\multicolumn{2}{|c|}{$\begin{array}{c}\text { B1 } \\
N=1\end{array}$}} & \multirow{2}{*}{\multicolumn{2}{|c|}{$\begin{array}{c}\mathrm{A} \\
N=8\end{array}$}} & \multirow{3}{*}{$p$-Value } \\
\hline & & & & & & & & & & \\
\hline & & $N$ & $\%$ & $N$ & $\%$ & $N$ & $\%$ & $N$ & $\%$ & \\
\hline CTXM & $N=22$ & 8 & $44 \%$ & 11 & $73 \%$ & 0 & 0 & 1 & $13 \%$ & 0.030 * \\
\hline TEM & $N=17$ & 7 & $39 \%$ & 5 & $33 \%$ & 0 & 0 & 5 & $63 \%$ & 0.310 \\
\hline SHV & $N=7$ & 4 & $22 \%$ & 1 & $7 \%$ & 0 & 0 & 2 & $25 \%$ & 0.556 \\
\hline
\end{tabular}

\section{Materials and Methods}

\subsection{Collection of Samples}

Urine samples were obtained from cancer patients suffering from urinary tract infection admitted at Assuit university hospitals from March 2018 to March 2019. Mid-stream urine samples were collected in sterile, dry containers after cleaning the genital area [52]. The processing of collected urine samples was done quickly to avoid contamination. Samples that could not be processed immediately were refrigerated at $4{ }^{\circ} \mathrm{C}$ for a few hours [53].

\subsection{Microscopic Examination of Urine Samples}

The collected urine samples were examined microscopically for pus cell count by high power field (HPF); pyuria means >5-10 leukocytes/HPF [54]. A gram-stained smear of the uncentrifuged urine samples was examined. A positive smear was defined by the presence of more than two bacteria per oil immersion field [55].

\subsection{Viable Count}

Viable Count was performed for urine samples using the pour plate method. The presence of $\geq 10^{5} \mathrm{CFU} / \mathrm{mL}$ was considered as significant bacteriuria, whereas lower numbers of organisms were considered as insignificant bacteriuria [56]. 


\subsection{Isolation and Identification of E. coli Isolates}

Urine samples were centrifuged at $4000 \mathrm{rpm}$ for $5 \mathrm{~min}$. The sediment was streaked on CLED agar medium, EMB medium and MacConkey agar medium (Oxoid, Basingstoke, UK). Then these media were incubated at $37^{\circ} \mathrm{C}$ for $24 \mathrm{~h}$. The isolated bacteria were then identified by using Gram stain and their biochemical characteristics. These included an indole production test, methyl-red test, Voges-Proskauer test, citrate utilization test, triple sugar iron agar test, and sugar fermentation patterns (Oxoid, Basingstoke, UK) [57].

\subsection{Antimicrobial Susceptibility Patterns of Uropathogenic E. coli Isolates}

All isolates were screened for susceptibility to twelve antimicrobial agents, namely amikacin (AK, $30 \mu \mathrm{g})$, gentamicin $(\mathrm{CN}, 10 \mu \mathrm{g})$, aztreonam (AZT, $30 \mu \mathrm{g})$, cefepime (FEP, $30 \mu \mathrm{g})$, cefotaxime (CXT, $30 \mu \mathrm{g})$, ceftazidime (CAZ, $30 \mu \mathrm{g})$, ceftriaxone $(\mathrm{CRO}, 30 \mu \mathrm{g})$, imipenem (IMP, $10 \mu \mathrm{g})$, ciprofloxacin $(\mathrm{CIP}, 5 \mu \mathrm{g})$, levofloxacin (LEV, $5 \mu \mathrm{g})$, nitrofurantoin (F, $300 \mu \mathrm{g})$, trimethoprim/sulfamethoxazole (SXT, 1.25/23.75 $\mu \mathrm{g}$ ) and colistin sulfate powder. All discs were supplied from (Bioanalyse, Ankara, Turkey)while colistin sulfate powder was supplied from (Merck, Darmstadt, Germany) All antimicrobial agents were determined by the disc diffusion method (except colistin sulfate) in accordance with the guidelines of the Clinical and Laboratory Standards Institute [58]. The results was interpreted according to Clinical Laboratory Standard Institute [59]. Broth microdilution was performed to determine the minimum inhibitory concentration (MIC) of colistin in cation-adjusted Mueller Hinton broth according to Clinical and Laboratory Standards Institute (CLSI) guidelines [60]. European Committee on Antimicrobial Susceptibility Testing (EUCAST) breakpoints were used for interpretation of colistin MIC results (with a susceptible breakpoint of al Susceptibility Testing (EUCAST) breakpoint $>2 \mathrm{mg} / \mathrm{L}$ ) [61].

\subsection{Phenotypic Detection of Extended-Spectrum $\beta$-Lactamases}

\subsubsection{Screening of ESBL-Production}

UPEC isolates that displayed decreased susceptibility to one or more of ceftazidime, aztreonam, cefotaxime or ceftriaxone were considered as potential ESBL-producing isolates according to CLSI, 2016 [59].

\subsubsection{Double-Disc Synergy Test (DDST)}

A Muller-Hinton agar plate (Oxoid, Basingstoke, UK) was inoculated with bacterial suspension matched with $0.5 \mathrm{McF}$ arland turbidity standards to nearly $10^{8} \mathrm{CFU} / \mathrm{mL}$ as recommended for the standard disc diffusion susceptibility test. The following discs, namely ceftazidime (30 $\mathrm{\mu g})$, aztreonam $(30 \mu \mathrm{g})$, cefotaxime $(30 \mu \mathrm{g})$, and ceftriaxone $(30 \mu \mathrm{g})$, were placed $20 \mathrm{~mm}$ (center to center) from the amoxicillin/clavulanic acid disc $(20 \mu \mathrm{g} / 10 \mu \mathrm{g})$. Following incubation for $24 \mathrm{~h}$ at $37^{\circ} \mathrm{C}$, the enhancement of the zone of inhibition between a $\beta$-lactam disc and that containing the $\beta$-lactamase inhibitor was indicative for the presence of an ESBL [62].

\subsection{Genotypic Detection of ESBL Genes by a Polymerase Chain Reaction}

\subsubsection{Extraction of Genomic DNA from Bacterial Culture}

The Quick DNA universal kit was used for Genomic DNA extraction according to the protocol provided by the manufacturer (Zymo Research, Irvine, CA, USA, catalog No. D 4068).

\subsubsection{Amplification of DNA by PCR}

The primer sequences used for the detection of bla TEM, bla SHV and bla CTXM are shown in Table 6. The PCR reaction for each gene was performed in a final volume of $25 \mu \mathrm{L}$ containing $12.5 \mu \mathrm{L}$ of $2 x$ master mix (BIOLINE, London, UK), $1 \mu \mathrm{L}$ of DNA template, $9.5 \mu \mathrm{L}$ of sterile distilled water and $1 \mu \mathrm{L}$ of each primer in a thermal cycler (Biometra, UNO-Thermo block, Macclesfield, UK). 
Table 6. PCR primers for detection of the bla TEM gene, bla SHV gene and bla CTXM gene.

\begin{tabular}{|c|c|c|c|}
\hline Gene & Primer Sequence $\left(5^{\prime}-3^{\prime}\right)$ & Size (bp) & References \\
\hline bla CTXM & $\begin{array}{l}\text { F: TTTGCGATGTGCAGTACCAGTAA } \\
\text { R: CGATATCGTTGGTGGTGCCATA }\end{array}$ & 544 & [63] \\
\hline bla TEM & $\begin{array}{l}\text { F: ATGAGTATTCAACATTTCCG } \\
\text { R: CTGACAGTTACCAATGCTTA }\end{array}$ & 867 & [64] \\
\hline bla SHV & $\begin{array}{l}\text { F: GGTTATGCGTTATATTCGCC } \\
\text { R: TTAGCGTTGCCAGTGCTC }\end{array}$ & 867 & {$[64]$} \\
\hline
\end{tabular}

The following conditions were used for amplification of the bla CTXM gene: an initial denaturation step at $94{ }^{\circ} \mathrm{C}$ for $2 \mathrm{~min}$, followed by thirty-five cycles consisting of denaturation at $95^{\circ} \mathrm{C}$ for $20 \mathrm{~s}$, annealing at $53{ }^{\circ} \mathrm{C}$ for $30 \mathrm{~s}$ and extension at $72{ }^{\circ} \mathrm{C}$ for $30 \mathrm{~s}$; and with a final extension at $72{ }^{\circ} \mathrm{C}$ for $3 \mathrm{~min}$. The conditions for amplification of the bla TEM gene were as follows: an initial denaturation at $96^{\circ} \mathrm{C}$ for $5 \mathrm{~min}$, followed by thirty-five cycles of $96^{\circ} \mathrm{C}$ for $1 \mathrm{~min}, 44^{\circ} \mathrm{C}$ for $1 \mathrm{~min}$, and $72{ }^{\circ} \mathrm{C}$ for $1 \mathrm{~min}$; and with a final extension at $72{ }^{\circ} \mathrm{C}$ for $10 \mathrm{~min}$. While the conditions for amplification of the bla SHV gene were as follows: an initial denaturation at $96^{\circ} \mathrm{C}$ for $5 \mathrm{~min}$, followed by thirty-five cycles of $96^{\circ} \mathrm{C}$ for $1 \mathrm{~min}, 59^{\circ} \mathrm{C}$ for $1 \mathrm{~min}$, and $72{ }^{\circ} \mathrm{C}$ for $1 \mathrm{~min}$; and with a final extension at $72{ }^{\circ} \mathrm{C}$ for $10 \mathrm{~min}$.

\subsubsection{Phylogenetic Group Typing}

Strains were assigned to one of the four E. coli phylogenetic groups (A, B1, B2 and D) using a triplex PCR based on the presence or absence of two marker genes (chuA and yjaA) and the DNA fragment TSPE4.C2. According to the PCR-based method described by (Clermont et al., 2000), the primer sequences used for detection of $c h u A$, yjaA and the DNA fragment TSPE4.C2 are shown in Table 7).

Table 7. PCR primers for phylogenetic typing.

\begin{tabular}{|c|c|c|c|}
\hline Gene & Primer Sequence $\left(5^{\prime}-3^{\prime}\right)$ & Size (bp) & References \\
\hline chuA & $\begin{array}{l}\text { F: GAC GAA CCA ACG GTC AGG AT } \\
\text { R: TGC CGC CAG TAC CAA AGA CA }\end{array}$ & 279 & \\
\hline yjaA & $\begin{array}{l}\text { F: TGA AGT GTC AGG AGA CGC TG } \\
\text { R: ATG GAG AAT GCG TTC CTC AAC }\end{array}$ & 211 & [7] \\
\hline TspE4.C2 & $\begin{array}{l}\text { F GAG TAA TGT CGG GGCATT CA } \\
\text { R: CGC GCC AAC AAA GTA TTA CG }\end{array}$ & 152 & \\
\hline
\end{tabular}

The triplex PCR assays for phylogenetic group typing were performed in a final volume of $25 \mu \mathrm{L}$ containing $12.5 \mu \mathrm{L}$ of $2 x$ master mix (BIOLINE, London, UK), $2 \mu \mathrm{L}$ of DNA template, $8.5 \mu \mathrm{L}$ of sterile distilled water and $1 \mu \mathrm{L}$ of each primer in a thermal cycler (Biometra, UNO-Thermo block). DNA amplification was carried out according to the following thermal conditions: Initial denaturation at $94{ }^{\circ} \mathrm{C}$ for $4 \mathrm{~min}$, thirty cycles consisting of denaturation at $94{ }^{\circ} \mathrm{C}$ for $5 \mathrm{~s}$, annealing at $59^{\circ} \mathrm{C}$ for $10 \mathrm{~s}$ and extension at $72{ }^{\circ} \mathrm{C}$ for $30 \mathrm{~s}$, and then the final extension step at $72{ }^{\circ} \mathrm{C}$ for $5 \mathrm{~min}$.

\subsubsection{Detection of PCR Products by Agarose Gel Electrophoresis}

The PCR products were separated by $2 \%$ agarose gel electrophoresis (ApplichemGmbh, Darmstadt, Germany), stained with ethidium bromide (Sigma-Aldrich, Germany) for 45 min under $80 \mathrm{~V}$ in $1 \mathrm{X}$ trisborate EDTA (TBE) buffer and visualized by ultraviolet Tran's illuminator (HeroLab UVT-20M, Wiesloch, Germany).

\subsection{Statistical Analysis}

The collected data were statistically analyzed using the Statistics Package for Social Sciences (SPSS) version 21. The difference was considered to be statistically significant when $p \leq 0.05$. 


\section{Conclusions}

EP-UPEC strains showed multidrug resistance and the most effective drug was imipenem. CTX-M was the most prevalent ESBL genotype and the majority of EP-UPEC strains had more than one ESBL gene.

Our findings showed that group B2 and group D were the most predominant phylogenetic groups among cancer patients infected with UPEC. In addition, we observed that certain polygenetic groups are more resistant than others, which could be due to greater exposure of certain phylogenetic groups to antimicrobials. Other studies among cancer patients in other regions are needed to provide a greater understanding of the prevalence of antimicrobial drug resistance and the geographic distribution of E. coli phylogenetic groups.

Regular study of antibiotic resistance patterns among cancer patients will help clinicians to prescribe the most appropriate antibiotic and to avoid further development of antimicrobial drug resistance.

Author Contributions: Data curation, H.M.H.; formal analysis, A.T.M., H.M.H., and R.A.I.; methodology, A.T.M., H.M.H., R.A.I., and M.T.S.; supervision, H.M.H., M.T.S., and R.A.I.; writing—original draft, A.T.M., and H.M.H.; writing-review and editing, A.T.M., R.A.I., H.M.H., and M.T.S; follow up sample collection, A.G. All authors have read and agreed to the published version of the manuscript.

Funding: This research did not receive any specific grant from funding agencies in the public, commercial, or not-for-profit sectors.

Acknowledgments: The authors received no financial support for the research or publication of this article.

Conflicts of Interest: The authors declare no conflict of interest.

Limitation of the Study: Molecular characterization of imipenem-resistant E.coli was not done in this study due to lack of funding. In addition, studying different variants among the same class of ESBLs was not done due to lack of funding.

\section{References}

1. Drago, L.; Nicola, L.; Mattina, R.; De Vecchi, E. In vitro selection of resistance in Escherichia coli and Klebsiella spp. at in vivo fluoroquinolone concentrations. BMC Microbiol. 2010, 10, 119. [CrossRef]

2. Ashour, H.M.; El-Sharif, A. Species distribution and antimicrobial susceptibility of gram-negative aerobic bacteria in hospitalized cancer patients. J. Transl. Med. 2009, 7, 14. [CrossRef]

3. Nurain, A.M.; Bilal, N.E.; Ibrahim, M.E. The frequency and antimicrobial resistance patterns of nosocomial pathogens recovered from cancer patients and hospital environments. Asian Pac. J. Trop. Biomed. 2015, 5, 1055-1059. [CrossRef]

4. Babady, N.E. Laboratory diagnosis of infections in cancer patients: Challenges and opportunities. J. Clin. Microbiol. 2016, 54, 2635-2646. [CrossRef]

5. Thom, K.A.; Kleinberg, M.; Roghmann, M.-C. Infection prevention in the cancer center. Clin. Infect. Dis. 2013, 57, 579-585. [CrossRef]

6. Pitout, J. Extraintestinal pathogenic Escherichia coli: A combination of virulence with antibiotic resistance. Front. Microbiol. 2012, 3, 9. [CrossRef] [PubMed]

7. Clermont, O.; Bonacorsi, S.; Bingen, E. Rapid and simple determination of theEscherichia coli phylogenetic group. Appl. Environ. Microbiol. 2000, 66, 4555-4558. [CrossRef] [PubMed]

8. Kazemnia, A.; Ahmadi, M.; Dilmaghani, M. Antibiotic resistance pattern of different Escherichia coli phylogenetic groups isolated from human urinary tract infection and avian colibacillosis. Iran. Biomed. J. 2014, 18, 219. [PubMed]

9. Tancheva, S.; Micheva, I.; Marinova, I.; Bojchev, B.; Marinov, M.; Nenov, K.; Radev, R. Infections in urinary tract of patients with haematological malignancies undergoing antineoplastic therapy. Hematology 2006, 15, 95-97.

10. Yakovlev, S.; Romashov, S.; Sidorenko, S.; Eryomina, L. Urinary tract infection in patients of gynecological malignancies undergoing external pelvic radiotherapy. In Proceedings of the 15th European Congress of Clinical Microbiology and Infectious Diseases, Copenhagen, Denmark, 2-5 April 2005. 
11. Hachem, R.; Raad, I. Prevention and management of long-term catheter related infections in cancer patients. Cancer Investig. 2002, 20, 1105-1113. [CrossRef]

12. Bhusal, Y.; Mihu, C.; Tarrand, J.J.; Rolston, K. Incidence of fluoroquinolone-resistant and extended-spectrum $\beta$-lactamase-producing Escherichia coli at a comprehensive cancer center in the United States. Chemotherapy 2011, 57, 335-338. [CrossRef] [PubMed]

13. MuktaKhaparkuntikar, N.A.P. Urinary tract infection in cancer patients at government cancer hospital Aurangabad, India. Int. J. Curr. Microbiol. App. Sci. 2017, 6, 2259-2263. [CrossRef]

14. Chandra, V.; Goswami, P.N. Detection of TEM \& SHV genes in Extended Spectrum Beta Lactamase (ESBL) producing E. coli \& Klebsiella pneumoniae isolated from a tertiary care cancer hospital. Natl. J. Med. Res. 2014, 4, 201-204.

15. Sedighi, I.; Arabestani, M.R.; Rahimbakhsh, A.; Karimitabar, Z.; Alikhani, M.Y. Dissemination of extended-spectrum $\beta$-lactamases and quinolone resistance genes among clinical isolates of uropathogenic Escherichia coli in children. Jundishapur J. Microbiol. 2015, 8. [CrossRef]

16. Elsayed, T.; Ismail, H.; Elgamal, S.; Gad, A. The occurrence of multidrug resistant E. coli which produce ESBL and cause urinary tract infections. J. Appl. Microbiol. Biochem. 2017, 1, 2-8. [CrossRef]

17. Shatalov, A. Prevalence and antibiotic resistance pattern of Escherichia coli and Klebsiella pneumoniae in urine tract infections at the La Paz Medical center, Malabo, Equatorial Guinea. Open J. Med. Microbiol. 2015, 5, 177. [CrossRef]

18. Mahgoub, F.M.; El-Gamal, S. Microbiological profile of urinary tract infections with special reference to antibiotic susceptibility pattern of Escherichia coli isolates. Int. J. Curr. Microbiol. App. Sci. 2018, 7, 911-920.

19. Abdel-Moaty, M.M.; Mohamed, W.S.; Abdel-All, S.M.; El-Hendawy, H.H. Prevalence and molecular epidemiology of extended spectrum $\beta$-lactamase producing Escherichia coli from hospital and community settings in Egypt. J. Appl. Pharm. Sci. 2016, 6, 042-047. [CrossRef]

20. Khan, S.A.; Feroz, F.; Noor, R. Study of extended-spectrum $\beta$-lactamase-producing bacteria from urinary tract infections in Bangladesh. Tzu Chi Med. J. 2013, 25, 39-42. [CrossRef]

21. Sannes, M.R.; Kuskowski, M.A.; Johnson, J.R. Geographical distribution of antimicrobial resistance among Escherichia coli causing acute uncomplicated pyelonephritis in the United States. FEMS Immunol. Med. Microbiol. 2004, 42, 213-218. [CrossRef]

22. Shaikh, S.; Fatima, J.; Shakil, S.; Rizvi, S.M.D.; Kamal, M.A. Antibiotic resistance and extended spectrum beta-lactamases: Types, epidemiology and treatment. Saudi J. Biol. Sci. 2015, 22, 90-101. [CrossRef] [PubMed]

23. Falagas, M.; Karageorgopoulos, D.E. Extended-spectrum $\beta$-lactamase-producing organisms. J. Hosp. Infect. 2009, 73, 345-354. [CrossRef] [PubMed]

24. Shakya, P.; Shrestha, D.; Maharjan, E.; Sharma, V.K.; Paudyal, R. ESBL production among E. coli and Klebsiella spp. causing urinary tract infection: A hospital based study. Open Microbiol. J. 2017, 11, 23. [CrossRef] [PubMed]

25. Alqasim, A.; Abu Jaffal, A.; Alyousef, A.A. Prevalence of multidrug resistance and extended-spectrum $\beta$-lactamase carriage of clinical uropathogenic escherichia coli isolates in Riyadh, Saudi Arabia. Int. J. Microbiol. 2018, 2018. [CrossRef] [PubMed]

26. Al-Mayahie, S.; Al Kuriashy, J.J. Distribution of ESBLs among Escherichia coli isolates from outpatients with recurrent UTIs and their antimicrobial resistance. J. Infect. Dev. Ctries. 2016, 10, 575-583. [CrossRef] [PubMed]

27. Thabit, A.G.; El-Khamissy, T.R.; Ibrahim, M.A.; Attia, A.E. Detection of extendedspectrum beta-lactamase enzymes (ESBLS) produced by Escherichia coli urinary pathogens at assiut university hospital. Bull. Pharm. Sci. Assiut Univ. 2011, 34, 93-103.

28. MuKherjee, M.; BaSu, S.; MuKherjee, S.K.; MajuMder, M. Multidrug-resistance and extended spectrum beta-lactamase production in uropathogenic E. Coli which were isolated from hospitalized patients in Kolkata, India. J. Clin. Diagn. Res. 2013, 7, 449. [CrossRef]

29. Islam, M.S.; Yusuf, M.A.; Begum, S.A.; Sattar, A.A.; Hossain, A.; Roy, S. Extended-spectrum-beta-lactamase producing uropathogenic Escherichia coli infection in Dhaka, Bangladesh. Afr. J. Bacteriol. Res. 2015, 7, 1-7.

30. Al-Agamy, M.H.M.; Ashour, M.S.E.-D.; Wiegand, I. First description of CTX-M $\beta$-lactamase-producing clinical Escherichia coli isolates from Egypt. Int. J. Antimicrob. Agents 2006, 27, 545-548. 
31. Mekki, A.H.; Hassan, A.N.; Elsayed, D.E.M. Extended spectrum beta lactamases among multi drug resistant Escherichia coli and Klebsiella species causing urinary tract infections in Khartoum. Afr. J. Bacteriol. Res. 2010, 2, 18-21.

32. Abayneh, M.; Tesfaw, G.; Abdissa, A. Isolation of Extended-Spectrum $\beta$-lactamase-(ESBL-) Producing Escherichia coli and Klebsiella pneumoniae from Patients with Community-Onset Urinary Tract Infections in Jimma University Specialized Hospital, Southwest Ethiopia. Can. J. Infect. Dis. Med. Microbiol. 2018, 2018. [CrossRef] [PubMed]

33. Villanueva, F.D.; Tupasi, T.E.; Abiad, H.G.; Baello, B.Q.; Cardaño, R.C. Extended-spectrum $\beta$-lactamase production among Escherichia coli and Klebsiella spp. at the Makati Medical Center: Tentative solutions. Phil. J. Microbiol. Infect. Dis. 2003, 32, 103-108.

34. Chakraborty, A. Antibiotic Resistance in Extra Intestinal Pathogenic Escherichia Coli. J. Microbiol. Exp. 2017, 4, 000122. [CrossRef]

35. Zhao, R.; Shi, J.; Shen, Y.; Li, Y.; Han, Q.; Zhang, X.; Gu, G.; Xu, J. Phylogenetic distribution of virulence genes among ESBL-producing uropathogenic Escherichia coli isolated from long-term hospitalized patients. J. Clin. Diagn. Res. 2015, 9, DC01. [CrossRef]

36. Fam, N.; Gamal, D.; El Said, M.; Aboul-Fadl, L.; El Dabei, E.; El Attar, S.; Sorur, A.; Fouad, S.; Klena, J. Detection of plasmid-mediated AmpC beta-lactamases in clinically significant bacterial isolates in a research institute hospital in Egypt. Life Sci. J. 2013, 10, 2294-2304.

37. Azargun, R.; Sadeghi, M.R.; Barhaghi, M.H.S.; Kafil, H.S.; Yeganeh, F.; Oskouee, M.A.; Ghotaslou, R. The prevalence of plasmid-mediated quinolone resistance and ESBL-production in Enterobacteriaceae isolated from urinary tract infections. Infect. Drug Res. 2018, 11, 1007. [CrossRef]

38. Abdi, H.A.; Rashki, A. Comparison of virulence factors distribution in uropathogenic E. coli isolates from phylogenetic groups B2 and D. Int. J. Enteric. Pathog. 2014, 2, 1-5. [CrossRef]

39. Lee, J.; Subhadra, B.; Son, Y.J.; Kim, D.; Park, H.; Kim, J.; Koo, S.; Oh, M.; Kim, H.J.; Choi, C. Phylogenetic group distributions, virulence factors and antimicrobial resistance properties of uropathogenic Escherichia coli strains isolated from patients with urinary tract infections in South Korea. Lett. Appl. Microbiol. 2016, 62, 84-90. [CrossRef]

40. Johnson, J.R.; Stell, A.L. Extended virulence genotypes of Escherichia coli strains from patients with urosepsis in relation to phylogeny and host compromise. J. Infect. Dis. 2000, 181, 261-272. [CrossRef]

41. Picard, B.; Garcia, J.S.; Gouriou, S.; Duriez, P.; Brahimi, N.; Bingen, E.; Elion, J.; Denamur, E. The link between phylogeny and virulence inEscherichia coli extraintestinal infection. Infect. Immun. 1999, 67, 546-553. [CrossRef]

42. Ejrnæs, K.; Stegger, M.; Reisner, A.; Ferry, S.; Monsen, T.; Holm, S.E.; Lundgren, B.; Frimodt-Møller, N. Characteristics of Escherichia coli causing persistence or relapse of urinary tract infections: Phylogenetic groups, virulence factors and biofilm formation. Virulence 2011, 2, 528-537. [CrossRef] [PubMed]

43. Kanamaru, S.; Kurazono, H.; Nakano, M.; Terai, A.; Ogawa, O.; Yamamoto, S. Subtyping of uropathogenic Escherichia coli according to the pathogenicity island encoding uropathogenic-specific protein: Comparison with phylogenetic groups. Int. J. Urol. 2006, 13, 754-760. [CrossRef] [PubMed]

44. Alghoribi, M.F. Molecular Epidemiology, Virulence Potential and AntibioticSusceptibility of the Major Lineages of Uropathogenic Escherichiacoli; The University of Manchester: Manchester, UK, 2015.

45. Marialouis, X.A.; Santhanam, A. Antibiotic resistance, RAPD-PCR typing of multiple drug resistant strains of Escherichia coli from urinary tract infection (UTI). J. Clin. Diagn. Res. 2016, 10, DC05. [CrossRef]

46. Bashir, S.; Sarwar, Y.; Ali, A.; Mohsin, M.; Saeed, M.A.; Tariq, A.; Haque, A. Multiple drug resistance patterns in various phylogenetic groups of uropathogenic E. coli isolated from Faisalabad region of Pakistan. Braz. J. Microbiol. 2011, 42, 1278-1283. [CrossRef]

47. Adwan, G.; Issa, B.; Adwan, K. Virulence profile, fluoroquinolone and quinolone resistance of uropathogenic Escherichia coli isolates recovered from Thabet Hospital-Tulkarm, Palestine. Br. Microbiol. Res. J. 2015, 5, 412-423. [CrossRef]

48. Abdallah, K.S.; Cao, Y.; Wei, D.-J. Epidemiologic Investigation of Extra-intestinal pathogenic E. coli (ExPEC) based on PCR phylogenetic group and fimH single nucleotide polymorphisms (SNPs) in China. Int. J. Mol. Epidemiol. Genet. 2011, 2, 339. 
49. Iranpour, D.; Hassanpour, M.; Ansari, H.; Tajbakhsh, S.; Khamisipour, G.; Najafi, A. Phylogenetic groups of Escherichia coli strains from patients with urinary tract infection in Iran based on the new Clermont phylotyping method. BioMed Res. Int. 2015, 2015. [CrossRef] [PubMed]

50. Wang, Y.; Zhao, S.; Han, L.; Guo, X.; Chen, M.; Ni, Y.; Zhang, Y.; Cui, Z.; He, P. Drug resistance and virulence of uropathogenic Escherichia coli from Shanghai, China. J. Antibiot. 2014, 67, 799. [CrossRef] [PubMed]

51. Cristea, V.C.; Gheorghe, I.; Czobor Barbu, I.; Popa, L.I.; Ispas, B.; Grigore, G.A.; Bucatariu, I.; Popa, G.L.; Angelescu, M.-C.; Velican, A. Snapshot of Phylogenetic Groups, Virulence, and Resistance Markers in Escherichia coli Uropathogenic Strains Isolated from Outpatients with Urinary Tract Infections in Bucharest, Romania. BioMed Res. Int. 2019, 2019. [CrossRef]

52. Prandoni, D.; Boone, M.H.; Larson, E.; Blane, C.G.; Fitzpatrick, H. Assessment of urine collection technique for microbial culture. Am. J. Infect. Control 1996, 24, 219-221. [CrossRef]

53. Millar, L.K.; Cox, S.M. Urinary tract infections complicating pregnancy. Infect. Dis. Clin. 1997, 11, 13-26. [CrossRef]

54. Chu, C.M.; Lowder, J.L. Diagnosis and treatment of urinary tract infections across age groups. Am. J. Obstetr. Gynecol. 2018, 219, 40-51. [CrossRef] [PubMed]

55. Bachman, J.W.; Heise, R.H.; Naessens, J.M.; Timmerman, M.G. A study of various tests to detect asymptomatic urinary tract infections in an obstetric population. JAMA 1993, 270, 1971-1974. [CrossRef] [PubMed]

56. Birnie, K.; Hay, A.D.; Wootton, M.; Howe, R.; MacGowan, A.; Whiting, P.; Lawton, M.; Delaney, B.; Downing, H.; Dudley, J. Comparison of microbiological diagnosis of urinary tract infection in young children by routine health service laboratories and a research laboratory: Diagnostic cohort study. PLoS ONE 2017, 12, e0171113. [CrossRef]

57. Myer, K. Methods in biochemical identification of bacteria. Myer's and Koshi's manual of diagnostic procedures in medical microbiology and immunology/serology, Department of Clinical Microbiology, Christian Medical College, Vellore. Christ. Med. Coll. 2001, 195-202.

58. Clinical and Laboratory Standards Institute. Performance Standards for Antimicrobial Testing: Twenty-Sixth Informational Supplement M100-S26; CLSI: Wayne, PA, USA, 2016.

59. Gupta, V.; Singla, N.; Chander, J. Detection of ESBLs using third \& fourth generation cephalosporins in double disc synergy test. Indian J. Med. Res. 2007, 126, 486-488.

60. Edelstein, M.; Pimkin, M.; Palagin, I.; Edelstein, I.; Stratchounski, L. Prevalence and molecular epidemiology of CTX-M extended-spectrum $\beta$-lactamase-producing Escherichia coli and Klebsiella pneumoniae in Russian hospitals. Antimicrob. Agents Chemother. 2003, 47, 3724-3732. [CrossRef]

61. Oliver, A.; Weigel, L.M.; Rasheed, J.K.; McGowan, J.E.; Raney, P.; Tenover, F.C. Mechanisms of decreased susceptibility to cefpodoxime in Escherichia coli. Antimicrob. Agents Chemother. 2002, 46, 3829-3836. [CrossRef]

62. CLSI. Performance Standards for Antimicrobial Disk Susceptibility Tests, 12th ed.; CLSI Document M02-A12; CLSI: Wayne, PA, USA, 2015.

63. Wayne, P. Methods for Dilution Antimicrobial Susceptibility Tests for Bacteria That Grow Aerobically, 10th ed.; CLSI document M07-A10; Clinical and Laboratory Standards Institute: Wayne, PA, USA, 2015.

64. EUCAST. The European Committee on Antimicrobial Susceptibility Testing. In Breakpoint Tables for Interpretation of MICs and Zone Diameters, Version 7.1; EUCAST: Växjö, Sweden, 2017.

(C) 2020 by the authors. Licensee MDPI, Basel, Switzerland. This article is an open access article distributed under the terms and conditions of the Creative Commons Attribution (CC BY) license (http://creativecommons.org/licenses/by/4.0/). 